\title{
Human Resource Selection Approaches and Socially Responsible Strategy
}

\author{
Olga Starineca \\ University of Latvia
}

\begin{abstract}
The research focuses on the characterisation of theoretical aspects of human resource (HR) selection approaches and the analysis of these approaches within a socially responsible strategy and in the context of business sustainability creation. The main methods implemented are monographic research, scientific literature analysis, synthesis, and comparison. As a result, the HR selection concept development and application summary was created as well as the importance of HR selection within a socially responsible strategy was characterised.
\end{abstract}

Keywords - Corporate social responsibility, human resource selection.

\section{INTRODUCTION}

One of the most valuable organisation's resources is human resource (HR). This resource is distinct, because it requires a special emotional approach for its management. D. Farnham (2010) outlines that "yet almost every HR [HR department's] decision and issue poses ethical questions, since they deal with people issues covering recruitment and selection ...".

Nowadays several regulations and rules are related to HR selection and management. Furthermore, special attention is devoted to Socially Responsible (SR) organisations in Latvia that create an operational approach exceptional and attractive to employees. Based on the Sustainability Index (SI) data (Ilgtspējas Indekss, 2014), each year from 2010 to 2013, an increasing number of organisations in Latvia participated in the competition for the place in the SI rating, i.e., they were striving for social and employment development, including HR selection according to several world standards.

The author focuses on Corporate Social Responsibility's (CSR) influence on Human Resource Management (HRM). HR selection as an element of HRM happens a little bit different in SR organisations compared to the majority of other organisations. HR selection is an important SR organisations' function. These organisations implement CSR strategy or are trying to act socially responsible as much as possible in order to ensure the organisational sustainability in numerous aspects. Implementing HR selection, employees of the organisation create employer brand and stimulate organisational relations with potential and current employees as well as select the most suitable person for work at the organisation. This person should be one, who will be able to both create a competitive advantage for the organisation in future and effectively refresh Human Capital (HC).

The author assumes that SR organisations are the organisations that implement CSR or SR strategy/approach within the present research. It is also assumed that a concept "CSR approach" is equivalent of a concept "CSR strategy", and SR strategy equals to CSR strategy.

The objective of the research is description of the theoretical aspects of HR selection approaches. The author assesses similarities and differences of the approaches and analyses this approaches in the context of SR strategy implementation and organisations striving for sustainability.

The monographic research method, scientific literature analysis, synthesis, and comparison are the main methods used in the research.

The present research is part of broader research that is related to development of the holistic HR selection approach for SR organisations. The basic materials used are the previous studies on human resource management and corporate social responsibility, scientific literature (textbooks, scientific books, and articles), informative materials available online. The research results can be used for further studies on HR selection in the framework of corporate socially responsible strategy implementation.

\section{Personnel or Human Resource Selection and Its Elements}

Personnel are not simply company's human resources, who guide the business in the right direction, personnel could be defined as a stakeholder of the company, the interests and needs of which should be satisfied.

The author participated in the studies the result of which was the statement that Latvian and foreigner scientists use concepts "personnel" and "Human Resources" interchangeably with the same meaning - employees or people employed by the organisation (Lapina et al., 2012). The author uses the HRM concept instead of the concept "personnel management" popular in the Latvian scientific literature. This choice is determined by the holistic essence of HR concept. S. Werner et al. (2012) identified HR as "all of the people who currently contribute to doing the work of the organisation, as well as those people who potentially could contribute in future, and those who have contributed in the recent past". I. Lapina et al. (2012) outlined that "in 1980s in the USA the HRM concept was developed. It was not a formal change of the name [the personnel management was used to use before], it resulted from the change of attitude to the employed people in the organisation". Employees are both a resource to reach the organisational targets and a stakeholder of the organisation, whose interests the organisations are trying to satisfy. 
TABLE I

Description and Elements of Human Resource Selection (Created by the Author)

\begin{tabular}{|c|c|c|}
\hline Authors & HR selection description & HR selection elements/steps/methods \\
\hline $\begin{array}{l}\text { O. Lundy and } \\
\text { A. Cowling } \\
(2003)\end{array}$ & $\begin{array}{l}\text { Organisation newcomer recruitment and selection, an assessment and } \\
\text { decision-making process }\end{array}$ & $\begin{array}{l}\text { - Inspection of applications } \\
\text { - Selection interviews } \\
\text { - Inspection of references } \\
\text { - Medical examination and selection tests }\end{array}$ \\
\hline $\begin{array}{l}\text { D. Cooper et al. } \\
(2003)\end{array}$ & True and more suitable set of selection procedures for work fulfilment & $\begin{array}{l}\text { - Set of the candidate selection standards } \\
\text { - Selection interviews and other selection methods } \\
\text { - Evaluation of the candidates } \\
\text { - Decision-making on the candidate's selection }\end{array}$ \\
\hline $\begin{array}{l}\text { H. T. Graham and } \\
\text { R. Bennett (2003) }\end{array}$ & $\begin{array}{l}\text { Assessment of the candidates using a number of methods to make a de- } \\
\text { cision on the most suitable candidate. After this process a job offer to } \\
\text { the candidate follows }\end{array}$ & $\begin{array}{l}\text { - Inspection of applications } \\
\text { - Choice of the selection methods } \\
\text { - Notification of job offer } \\
\text { - Collection of the references } \\
\end{array}$ \\
\hline M. Kehre (2004) & $\begin{array}{l}\text { Examination, assessment and definition of the candidate's eligibility to } \\
\text { the job requirements }\end{array}$ & $\begin{array}{l}\text { - Assessment of the application letters and autobiographies } \\
\text { - Evaluation of references } \\
\text { - Application of tests } \\
\text { - Interviews } \\
\text { - Evaluation of information and decision-making } \\
\text { - Notification of the decision }\end{array}$ \\
\hline $\begin{array}{l}\text { W. L. French } \\
(2007)\end{array}$ & $\begin{array}{l}\text { Selecting internal or external candidates for permanent or temporary } \\
\text { work }\end{array}$ & $\begin{array}{l}\text { - Testing } \\
\text { - Examination of applications } \\
\text { - Physical examination } \\
\text { - Selection interviews } \\
\end{array}$ \\
\hline $\begin{array}{l}\text { M. Foot and } \\
\text { C. Hook (2008) }\end{array}$ & $\begin{array}{l}\text { Fulfilling selection tests and interviews with the most successful can- } \\
\text { didates according to the employment legislation, rules and previously } \\
\text { developed fair selection procedures and policies to promote a corpo- } \\
\text { rate strategy of the organisation }\end{array}$ & $\begin{array}{l}\text { - Selection interview } \\
\text { - Selection testing }\end{array}$ \\
\hline $\begin{array}{l}\text { I. Boitmane } \\
(2008)\end{array}$ & Aimed staff planning to attract eligible candidates and hire them & $\begin{array}{l}\text { - Development of the detailed job description } \\
\text { - Assessment of the application letters and autobiographies } \\
\text { - Job interviews and observations } \\
\text { - Surveys } \\
\text { - Psychological tests } \\
\text { - Job tasks } \\
\text { - Collection of the references }\end{array}$ \\
\hline $\begin{array}{l}\text { I. Ešenvalde } \\
(2008)\end{array}$ & $\begin{array}{l}\text { Selection of the most suitable candidate for an organisation and posi- } \\
\text { tion (closest match of the required skills, competences) from a pool of } \\
\text { candidates }\end{array}$ & $\begin{array}{l}\text { - Analysis of the documents } \\
\text { - Interviews, tests and role-playing games } \\
\text { - Notification of the decision }\end{array}$ \\
\hline $\begin{array}{l}\text { I. Vorončuka } \\
(2009)\end{array}$ & $\begin{array}{l}\text { Selection of the most suitable candidate from all applicants applying } \\
\text { the previously developed selection policy }\end{array}$ & $\begin{array}{l}\text { - Preselection (work with documents and applications, } \\
\text { check of references and health) } \\
\text { - Selection testing } \\
\text { - Selection interviews } \\
\text { - Final selection and selection evaluation }\end{array}$ \\
\hline $\begin{array}{l}\text { L. R. Dombrovska } \\
(2009)\end{array}$ & $\begin{array}{l}\text { Expression of the judgment on the candidate's abilities, characteristics } \\
\text { or personal talent, his/her suitability for the vacant position, motiva- } \\
\text { tion, as well as future potential evaluation }\end{array}$ & $\begin{array}{l}\text { - Analysis of submitted documents and applications } \\
\text { - Selection interviews } \\
\text { - Organisation, management and analysis of tests and tasks } \\
\text { - Selection of the candidate } \\
\text { - Decision announcement to the candidates } \\
\text { - Analysis of the selection process }\end{array}$ \\
\hline $\begin{array}{l}\text { M. A. Raphael } \\
(2009)\end{array}$ & $\begin{array}{l}\text { Determination of the candidate from a pool of the recruited candidates, } \\
\text { who will be more suitable for the organisation and position according } \\
\text { to the forecasts (predictions) }\end{array}$ & $\begin{array}{l}\text { - Research of the candidates' experience } \\
\text { - Testing of the candidates } \\
\text { - Selection interviews } \\
\text { - Reference checking } \\
\text { - Decision-making }\end{array}$ \\
\hline $\begin{array}{l}\text { M. Armstrong } \\
(2009)\end{array}$ & $\begin{array}{l}\text { Selection of the candidate according to the required competences, de- } \\
\text { veloped employment rules, terms and conditions as well as to the job } \\
\text { description }\end{array}$ & $\begin{array}{l}\text { - Sorting of the applications } \\
\text { - Selection interviews } \\
\text { - Selection testing } \\
\text { - Candidate evaluation } \\
\text { - Collection of the references } \\
\text { - Job offer } \\
\text { - Employment contract preparation }\end{array}$ \\
\hline G. Dessler (2010) & $\begin{array}{l}\text { Choosing the right candidate from the job applicants with screening } \\
\text { tools to seek success in job performance, costs and legal liability is- } \\
\text { sues }\end{array}$ & $\begin{array}{l}\text { - Checking of the candidates' experience } \\
\text { - Testing } \\
\text { - Interviews } \\
\text { - Checking of the experience and references } \\
\text { - Decision making on job offer to the exact candidate }\end{array}$ \\
\hline $\begin{array}{l}\text { S. Werner et al. } \\
(2012)\end{array}$ & $\begin{array}{l}\text { Sorting and ranging the most suitable candidates for the job and the or- } \\
\text { ganisation according to certain criteria as well as job offer afterwards }\end{array}$ & $\begin{array}{l}\text { - Candidates' sorting } \\
\text { - Candidates' ranging }\end{array}$ \\
\hline
\end{tabular}


HR selection used to be an HRM activity in the beginning. Afterwards, it was developed as a separate meaningful activity in science and practice. After 1920, the number of companies that developed their own "guidelines to effectively organise HR selection process and efficiency" increased in the USA (Boitmane, 2008). 1960 was a time of economic boom and low unemployment rates; hence, HR selection became more focused (Bloisi, 2006). In 1989, V. F. Cascio noted that the aim of assessment and selection program was to "identify a candidate for a job based on score high on selection measures that purport to assess knowledge, skills, abilities, or other characteristics that are critical for job performance”. In the 21st century, W. Bloisi (2006) defined HR selection as "the methods used to identify suitable staff who will match the requirements of the organisation".

Boitmane (2008) noted that "a necessity of [HR] selection process management in Latvia became topical in 1990 towards the increase in business development intensity". In 1999, D. Guest developed a list of good case practices of HRM that would lead to the excellent organisational performance. The first point in the list was "HR selection and the careful use of selection tests to identify those with potential to contribute".

"When the need for people has been ascertained, the next task is to find them, and ensure that the right people are selected and recruited for the organisation. If the wrong people are recruited then there could be difficulties in achieving organisational goals and business could suffer" (Bloisi, 2006). W. Bloisi (2006) highlights the necessary to select a candidate that exactly will match the set requirements, i.e., neither over-qualified nor under-qualified to avoid "serious implications for the organisation". Selected person will be responsible for the reputation of an organisation and stakeholders' needs satisfaction in future.

Various authors that write about HR selection mention selection and recruitment together. Across the authors' descriptions of human search, selection, and choice, it has been found that the selection is an intermediate step of HR selection process between the potential employees' recruitment and acceptance for the job. Firstly, the job requirements according to the job description and organisational principles should be defined. (Armstrong, 2009) The next step usually is development of job advertisement. This step is essential, because precise job advertisement is a tool for both the HR selection specialist and the exact professional level specialist attraction. The job advertisement helps to sort people with exact qualification (Bloisi, 2006). Then planning of potential employee attraction and recruitment activities happen followed by necessary human resource searching and then recruitment implementation. There can be various sources and approaches used, e.g., M. Armstrong (2009) notes that it is possible to "reviewing and evaluating alternative sources of applicants, inside and outside the company: advertising, e-recruiting, agencies and consultants". The final stages are the process of candidate selection, notification of a job offer to the exact candidate, decision-making on acceptance of the selected candidate as well as the selected candidate's decision on the job offer acceptance (Werner et al., 2012; Armstrong, 2009).

There are several HR selection process definitions by the $21 \mathrm{st}$ century scientists (see Table I). On the basis of the description analysis, it is possible to conclude that before HR selection organisations should be aware of:

- organisational principles, terms and conditions;

- culture of organisation, operating principles and strategies;

- competences (selection criteria) that correspond to a job. According to the definitions observed, HR selection is sorting and ordering of candidate applications based on the job applicants' examination, test, and interview results according to the set criteria. Important activities of the HR selection process are mainly assessment and decision-making when selecting the best candidate. The most important part of HR selection, however, could be preparation. An HR specialist should be aware of job specifics and design, company's culture, objectives and requirements to employees, as well as certain legislation, norms and ethical principles. First, business needs and job requirements should be defined. Afterwards, selection criteria, additional tools and required candidate competencies, could be chosen.

For example W. Bloisi (2006) mentions:

- IQ (Intelligence Quotient) tests;

- psychological tests;

- examination of selection criteria (anthropological, body and health parameters, and medical examination mentioned by O. Lundy and A. Cowling (2003)).

There are authors, who note also drug tests as one of the determining selection tests (Graham \& Bennett, 1998; French, 2007). Drug testing is essential when selecting candidates for positions related to physically demanding and safety issues (sports, passenger and cargo transport, etc.).

Apart from various types of testing, it is possible to check and examine abilities and skills of the candidates by (Lundy \& Cowling, 2003; Cooper et al., 2003; Raphael, 2009; Armstrong, 2009):

- interviews (individual or one-on-one, group, panel, stress interviews, work sample, structural and non-structural);

- reference reception and checking;

- graphology;

- astrology.

Employee can be chosen from the current company's employees or from the external environment (local or foreign labour market) candidates. There are a lot of HR selection methods and approaches. The main scheme of selection has not been changed since the beginning of this century - application sorting, reference collection and check, selection interviews, different kinds of testing, evaluation of candidates and decision-making on the most suitable candidate and a job offer proposal. The information technologies do not stop developing; therefore, HR selection specialists can choose the suitable selection method using different kinds of tools (special software, social networks, Internet applications and tools, etc.).

Even candidates' physical presence in the selection interview or negotiation meeting is not strictly necessary nowadays. For audio and video interviews, organisations often use telephones (Boitmane, 2008), Google Hangout application, Skype calls. Candidates can record their Video Résumé (Cascio, 1989) and answers on the questions applying taketheinterview.com service or post and share information on professional background and 
references on the LinkedIn profile. For knowledge and skills examination, on-line testing can be used (Dessler, 2010). For competence or exact criteria based selection a certain database with logged assess for HR selection specialists can be used (Ešenvalde, 2008).

The candidates can be given to make group or individual tasks. One of the basic approaches to the HR selection is competence-based selection. Knowing competences needed for the exact job position, the selection specialist can choose the appropriate examination method (Armstrong, 2009). The job analysis goes before setting the competences.

A. Vīksna (1999) summarised competences by the groups of criteria; their importance depends on job specification:

- physical criteria (vision, physical parameters, immunity, etc.);

- psychological criteria (ability to make decisions, stress resistance, reaction, monotonous sensitivity, etc.);

- socio-psychological criteria (ability to cooperate with other people, management abilities, etc.);

- special or professional criteria.

I. Boitmane (2008) writes that HR selection is tightly connected to psychology. Necessity to assess the candidates from the psychological point of view appeared because of selection specialists, who noticed that the working processes at organisations required employees' interaction with each other and communication (Boitmane, 2008). Socio-psychological criteria have a special meaning, if a job is related to HR interaction (e.g., team or working group activities).

Examining and assessing the candidates' competencies, experience, qualification, education, and personal character traits as well as preparing for the HR selection process in general, the importance of the HR selection in the organisational culture and goals reaching should be given special attention. In 1985, M. E. Porter outlined that HR strategies had a connection with competitive strategies, i.e., to maintain the competitive advantage from the quality perspective, organisations need to "use sophisticated selection procedures to recruit people who are likely to deliver quality and high levels of customer service" (Porter, 1985). For example, Microsoft employees' selection process presumes having a specialist ("as appropriate" interviewer) outside the selection group during the selection interviews. The specialist is "a person really solidly grounded in Microsoft culture and committed to making sure that we hire only those who are going to be good Microsoft people, not just good people for specific jobs" (Bartlett \& Wozny, 2001).

Ethical consideration should be taken into account for internal as well as external HR selection. Ethical behaviour to candidates is one of the actual considerations of modern organisations' HR selection process. According to M. Armstrong (2009), ethical behaviour during HR selection process includes deliberate and timely responses to the candidates, informing them about application acceptance and selection stage results, responding to candidates' requests to explain, why they did not pass to the next phase of the selection. Ethical behaviour during HR selection depends on HR selection implementers' "conduct and values as professionals, and the ethical standards of their firms" (Armstrong, 2009).
Having an independent survey as a "mystery shopper" (secret agents), the author made some conclusions on the observations. There are organisations in Latvia that give their candidates for a vacant position to sign a confirmation document. The document consisting of a few sentences states that the candidate has not been discriminated in any way and offended or encroached in any other way during the interview. This activity could be mentioned as an example of ethical behaviour promotion during the HR selection process.

A. Milts noted that "nowadays successful management and governance cannot be imagined without respect of fundamental ethical principles and values that usually already are highlighted in the professional codes of ethics of the certain activity sectors" (Ilmete \& Roišs, 1998). People - candidates for a certain vacant position at an organisation, who are participating in the selection process, are potential human resources of the organisation that will help to reach organisational goals, as well as its [the organisation's] external stakeholder. Implementing the HR selection, organisations need to take care of relationship establishment with its potential employees. Stakeholder theory that is a basic part of CSR helps to understand essence and importance of the relationship creation implementing HR selection activities on each stage.

\section{Corporate Social Responsibility, Social Responsibility and Sustainability}

Mostly all socially responsible companies would like to maintain their competitive advantage, have good relationships with their stakeholders, and strive for sustainable business development.

The new stage of corporate social responsibility - CSR $2.0-$ has a shared value (for the company and society) on top of its development. Even though it is a strategic approach to the business, shared value creation philosophy influences every human resource management activity. The most important thing is to pay attention to the fact that social responsibility strategy is based on forming relationships with the company's stakeholders.

The popularity of the business sustainability issue increases in the Latvian and foreign business environment. In 2010, the initiative of the Sustainability Index appeared in Latvia. The methodology of SI is based on the example of the Dow Jones Sustainability Index and Business in the Community CR Index as well as takes into account ISO 26000 Social Responsibility standard and the Global Reporting Initiative's (GRI) G3 framework (Lapina et al., 2012).

Lapina et al. (2012) recognise that "socially responsible strategy has already become an integral part of many competitive and sustainable enterprises' daily activities. CSR concept provides organisation stakeholders all interests' satisfaction". The author adheres to the following CSR and SR organisation concept definitions within this paper (European Commission, 2001):

- CSR is a concept that helps organisations to integrate social and environmental aspects into their activities and cooperation with their stakeholders;

- SR organisation is an organisation, which besides the legislative requirement fulfilment invests "more" in the human capital, environment issues, and relationships with its stakeholders. 
R. E. Freeman's Stakeholders Theory formulated in 1980 should be noted in the CSR context (Mitchell et al., 1997). R. E. Freeman (1984) defined stakeholders as "any group or individual, who can affect or is affected by the achievement of the organisations objectives". "Such a strategy would ensure the organisation's long-term success" (Lapina et al., 2012). Savage et al. (1991) highlighted that SR organisation creates relationships with its stakeholders for sustainable business maintenance.

A. B. Carrol (1991) proposed one of the CRS comprehensive typologies. The four levels of the pyramid are the economical responsibility, legal responsibility, ethical responsibility and the discretionary or philanthropic level on the top. CSR is tightly connected to the ethics theory, which is viewed towards the Behaviour Theory context (Griseri \& Seppala, 2010). Each Carrol's pyramid level contains various aspects related to certain relationships development with the relevant stakeholders.

In 1997, J. Elkington developed the Triple Bottom Line concept that is based on the three elements (Rahman, 2011):

- people (social responsibility);

- planet (responsibility for environment);

- profit (economical responsibility).

In general, this concept is coherent with Carrol's CSR division by levels. It shows not risks rather CSR collaboration object dependent levels of responsibility; it has a sustainability basement (Cato, 2009). Carrol's four levels combine all three Elkington's elements.

CSR approach has been developed and is applicable in practice. In the scientific world, however, this approach was both criticised and supported. In 2011, W. Visser's CSR 2.0 proved CSR approach essential changes in the development way. Visser (2011) outlines five elements of CSR 2.0 principles:

1. creativity;

2. scalability;

3. responsiveness;

4. glocality;

5. circulation.

In contrast to Carrol's pyramid, Visser mentions Guatemalan sugar production cooperative, which has its own CSR pyramid - instead of legal, ethical, and philanthropic level, it has responsibility for employees' families, community and political involvement (Visser, 2011). This example shows SR transition from formal and abstract expression to the understandable for public level of expression.

Visser (2011) pays attention to ontological CSR 1.0 changes on the meta level (see Fig. 1) and its methodological changes on the micro level - transition from process standards to the result standards, from charity projects to social entrepreneurship, from CSR indices to CSR ratings, etc. CSR approach is not quite so straightforward; it is focused on collaborative benefits, it is not perceived as a separate project rather it is an integrated part of shared activity culture. This Visser's new generation CSR approach description has something in common with other authors' descriptions of organisation SR approach to the business activities.

M. E. Porter and M. R. Kramer's (2011) approach - Creating Shared Value (CSV) - can also be called a new generation CSR.
CSR focuses on interdependencies between social and economic processes; it unites all stakeholders. As a result, CSV gives output to both the organisation and its stakeholders.

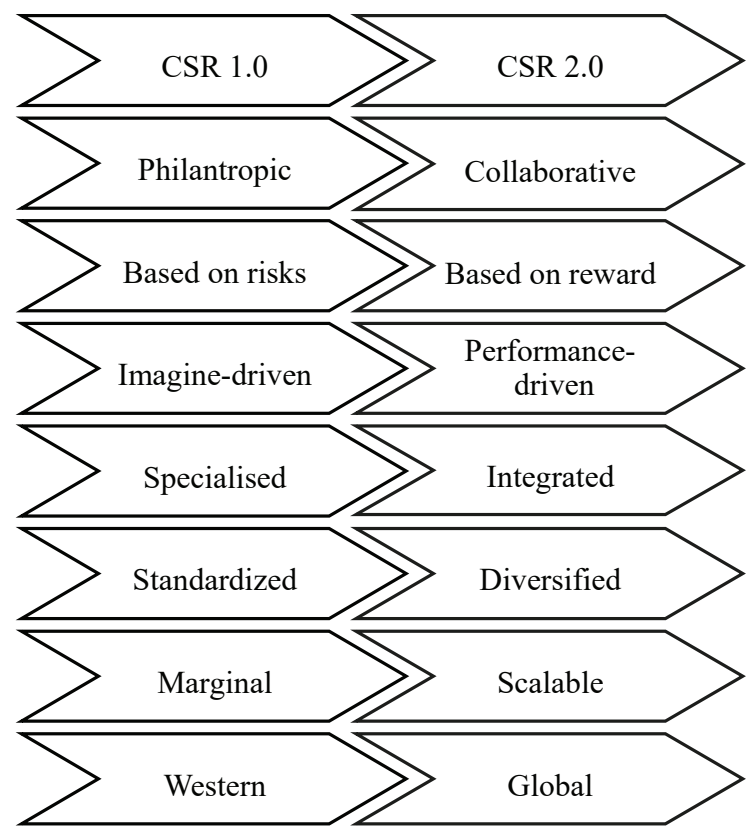

Fig. 1. CSR 1.0 transition to CSR 2.0 - ontological changes on the meta level (created by the author based on Visser, 2011).

Summarising studied approaches and concepts, Fig. 2 was created. It reflects wideness of the approach. It is possible to reach sustainability, if the organisation does more than a simple SR organisation does, i.e., the organisation needs to implement the CSR strategy and tries to satisfy its stakeholder's interests as much as possible. It is possible to reach sustainability not only implementing activities that presume the CSR strategy but also doing some other additional activities.

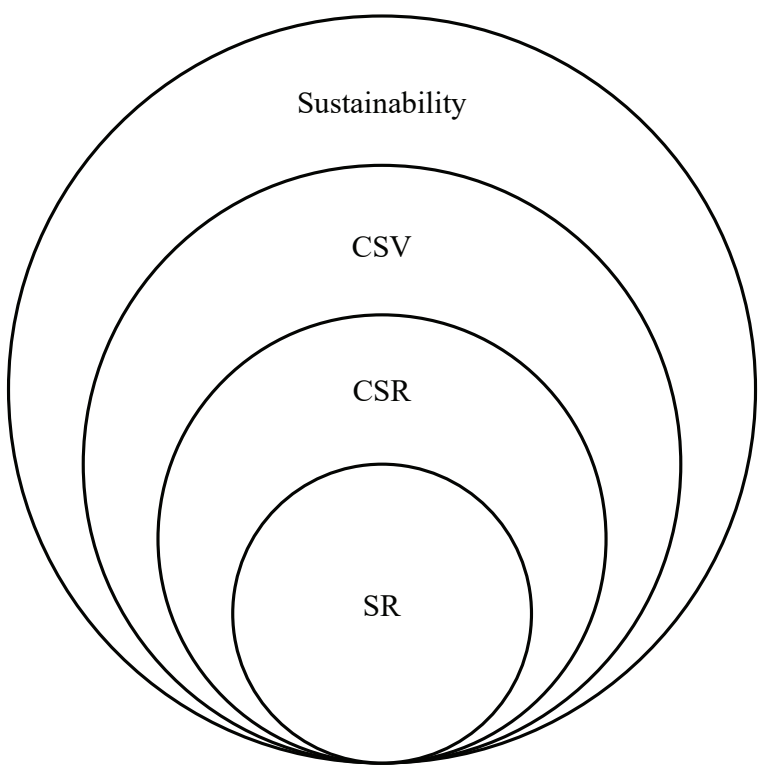

Fig. 2. SR, CSR, CSV, and sustainability comparison (created by the author). 
Potential employees admit that CSR and SR become more and more important criteria when choosing a working place (organisation to work for). Sustainability is tightly related to CSR. Sustainability refers to the organisation's ability to produce goods or deliver services without damaging the environment or depleting resources (Snell \& Bohlander, 2011). HR selection process itself is special for SR organisations, because it requires term fulfilment and certain approach application creating and developing relationships with potential employees.

\section{Human Resource Selection in the Context of Social Responsibility}

It is important to see potential and current employees as stakeholders during the human resource selection process. The exertion of a socially responsible strategy is especially relevant during the HR selection process.

HR selection procedure based on a socially responsible approach in business presumes compliance with regulations on each CSR level presented by Carroll (1991). Economic benefits of the organisation hiring a person for work, labour law, social guarantees, and fair selection process without discrimination and in terms of ethical principles - all these statements related to the HR selection process are the reflection of CSR components.

In spite of CSR concept changes and development, adaptation to the actualities, SR organisations still have an objective to promote and develop their positive employer brand. CSR and SR approach application helps organisations reach this objective internally and externally. From the human resource selection perspective, work with stakeholders from both external and internal organisational environments is essential, because the organisation might implement external as well as internal HR selection.

HR selection might be part of the quality management system. It is important to define a customer's needs and try to find an employee, who will be able to satisfy the customers' needs the best towards his/her work (Cooper et al., 2003). There are organisations that raise employees according to their needs, who will be able to develop following new tendencies on the market and professionally satisfy clients' needs and wishes. For example, Accenture Latvia organises professional courses for pupils, youth, and adults in the Accenture Programming Schools (Accenture Latvia, 2013). Later on, the best alumni of the school could become the employees of Accenture.

It is essential to pay attention to the holistic HRM approach. Each HRM process and activity should be coherent with internal factors of the organisation (business strategy, organisational culture, structure, etc.). HRM strategy depends on those factors. Implementing the HRM strategy, each HRM activity including HR selection gives a certain output/result that shows a level of stakeholders' interests (Lapina et al., 2013). Stakeholders' interests are different. In case of HR selection, there are various interests and wishes of potential employees. They could be related to ethical, legal, economical, or other issues. Hence, the organisations have to control (pay attention to) the stakeholders' interests, all external and internal factors selecting HR. SR organisations are mainly characterised by a comprehensive/holistic operation in the framework of HR selection process (Lapina et al., 2013).
In the context of strategy, it is worth noting the strategic HRM. HRM strategy is a functional level business strategy that comes out of competitiveness strategy (Lundy \& Cowling, 2003; Dessler, 2010).

K. Legge (1995) considers that "human resources are valuable and a source of competitive advantage". L. Gratton (2000) pays attention to the cases, when resources, including human resources, are a long-term competitive advantage (Gratone, 2004):

- if they are exceptional/exclusive (not all competitors have them);

- if they are valuable (so they essentially influence the work);

- if they cannot be imitated, (so the competitors could not easily copy or substitute them).

Armstrong and Baron (2002) state that "people and their collective skills, abilities and experience, coupled with their ability to deploy these in the interests of the employing organisation, are now recognised as making a significant contribution to organisational success and as constituting a major source of competitive advantage" (Armstrong, 2009).

E. Clarke (2006) suggests that "there is evidence that tapping into this interest and engaging staff is also likely to benefit the company brand and reputation". According to the first version of CSR, SR operational principles also influence organisations as employers' image.

As it has already been mentioned, CSR becomes one of the important criteria for job seekers choosing which organisation they want to work for. CSR could help organisation building/developing relationships with stakeholders, including employees and potential employees, during HR recruitment and selection, engagement and retention. Not only generation Y representatives, but also generation $\mathrm{X}$ specialists prefer rather to work for the organisation that will respect or have common values as they have. "Present and future employees are placing increasing value on the credibility of an organisation's brand. Employers are using the positive aspects of their brand in recruiting, motivating, and retaining highly skilled people." (Foot \& Hook, 2008). Symbiosis of employer and employee is typical of the new generation CSR. Both parties are partners now. Each of them have its own interests, wishes, and requirements. Furthermore, both are not able to reach the goals without collaboration. This kind of cooperation provides each partner its own advantage. Dessler (2010) mentions that the clearest organisational competitive strategy "usually depends on highly trained and committed employees." Some managers consider that their subordinates' abilities and motivation are a necessary source of the competitive advantage. Employees' excellence might mainly be experienced towards constant development, improvements, education, including time spent at the working place. Training and development of employees is necessary. It can motivate employees to work harder and show better performance. However, the organisations usually unconsciously prefer to employ people (specialists) that can immediately bring additional value to the organisation. The organisations need to realise the set of requirements of these kinds of candidates for a job position. They most probably want to be sure that they will be assessed, that their economic, legal, and ethical requirements will be taken into account. Based on the consideration, it can be concluded one more time that HR 
selection is an important activity, which has an important role from both corporative and social perspectives.

The European Commission (2001) outlines a non-discriminatory practice that is included into the responsible HRM practices. It means that SR organisation candidates' selection does not depend on the candidates' gender, age, work experience etc., so it helps to reduce unemployment and fight against social exclusion. Organisations should look at HR selection activities impact in sense that it is a more global, connecting influence of each activity implementation outcome on each HR selection stakeholder.

Based on summary from Table I, the author developed a list of HR selection activities/elements in the logical order:

1. development of a detailed job description;

2. candidates assessment standard determination;

3. choice of selection methods;

4. pre-screening (work with documents: candidate applications/application letters' review, assessment and sorting, candidates' document (resume/CV, certificates, diplomas, etc.) analysis/assessment; references and medical inspection);

5. research and verification of the candidates' experience;

6. selection interview with the preselected candidates, selection testing, medical testing/ physical examination and other selection method implementation (organisation, management and analysis of individual or group interviews, psychological, professional and other tests, surveys, role games, etc.);

7. collection, inspection and examination, evaluation of references about the candidates;

8. analysis of the collected data/information;

9. examination, sorting and rating of the candidates based on previous examination results;

10. decision-making on job offer to the certain candidate(s);

11. candidates' notification on the selection results and job offer expression;

12. development of the employment contract;

13. assessment and analysis of the selection process.

This list of the activities characterises the HR selection process in a comprehensive manner. Implementing the SR strategy, the fulfilment of all these activities requires the organisation's attention. Each activity needs to be coherent with the general HRM strategy. SR or CSR operational principles influence HRM strategy of the SR organisations.

As it has been examined in Section III of this paper, CSR principles can be divided into four levels. Fulfilling HR selection coherence with SR operational principles usually there are several outcomes that can be divided into HR, social, financial and performance results (see Fig. 3) (Lapiņa et al., 2013).

That means that developing, for example, a job description ethical principles should be taken into account, i.e., work should not be too specific, so people with certain disabilities or at a certain age cannot do it. The content of certain organisations' positions regulates law, terms, or other legislative documents that should be considered developing a job description. In addition, a process of job description development should ensure as less resource "consumption" as possible and as big financial and positive performance return as possible.

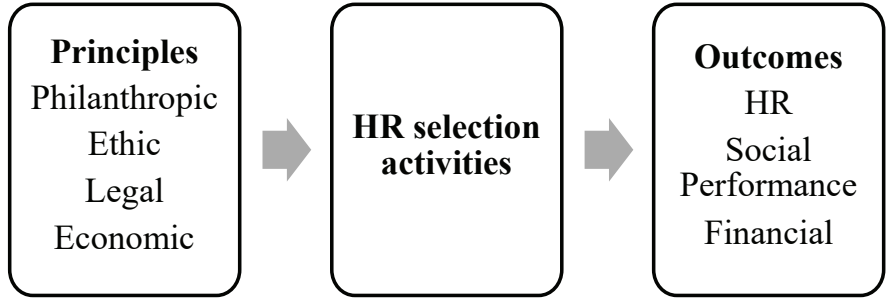

Fig. 3. HR selection connection with SR operational principles (created by the author).

From the philanthropy perspective, a detailed job description focuses on the improvement of humanity. In case of SR organisation, each HR selection activity result is related to the organisational interests' satisfaction (positively influencing the employer brand) as well as satisfaction of all other involved into the process stakeholders' interests.

I. Lapina et al. (2013) reviewed quite the same relationship. They developed the HRM holistic model (see Fig. 4). Implementing HRM activities (guided by principles, flow and range) based on HRM strategy, they are HR, performance, social and financial outcomes. These outcomes show to which extent stakeholders' interests and wishes is satisfied. This influences organisation's internal and external factors. One of internal factors is also an applied CSR approach. Based on this approach, organisations can develop and correct (modify) the HRM strategy (Lapinga et al., 2013).

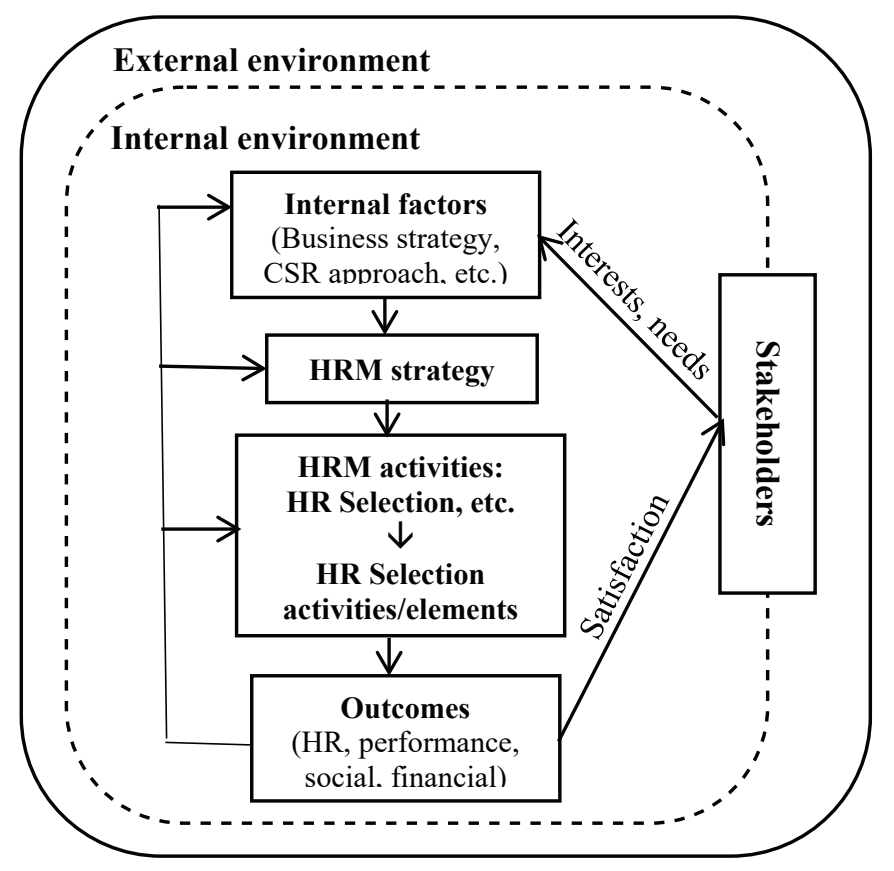

Fig. 4. HRM holistic model (created by the author based on Lapiņa et al., 2012).

Unlike SR organisations, other organisations, which apply quite the same implementation scheme of HR selection activities, rarely harmonise HR selection results with all CSR levels, sometimes they do not assess, how these results will affect implementation of general HRM and business strategies, as well as do not apply these results to the stakeholders. 
SR organisations are striving for sustainability in many aspects. They are trying to reach sustainability applying SR or CSR activities as the tools. Sticking to the SR operational principles of their activities, SR organisations create an exact plan of each activity implementation, motivating goals and assessing results.

\section{CONCLUSION}

The theoretical aspects of HR selection were described. The author summarised HR selection process definitions and approaches as well as the place of HR selection elements in the process of SR or CSR strategy implementation. As a result, a list of HR selection activities/elements in the logical order was developed. It reflects the whole range of HR selection activities that could be applied implementing HR selection process in a classical way. Unlike other organisations, SR organisations implement the activities as those that influence a general organisational strategy, and correspond to SR working principles.

HR selection process was not reviewed in detail in the context of social responsibility. However, implementation of SR strategy is directly dependent on employees that were selected for work at the SR organisation.

HR selection can be called a strategic activity of SR organisation. The properly selected candidate (employer) is investment to the competitiveness of the organisation. HR selection process has a "responsibility" for today and tomorrow. The organisation creates relationship with a stakeholder, develops the employer brand, acts strategically selecting HR for the position.

HR selection is an important part of a socially responsible strategy - this activity influences further business competitiveness as well as the company's image, employer brand and collaboration with its stakeholders. HR selection activities are a connection tool; they harmonise implementations aspects of planned and expected outcomes of SR strategy. Focus of socially responsible company managers should be directed to relationship creation and maintenance, especially during the HR recruitment and selection process.

SR organisations use the same HR selection methods and apply the same elements as other organisations; variation is possible depending on the specifics of vacant position. However, human resource selection process might be integrated into the human resource management process of the organisation and depends on the HRM strategy that might be affected by internal and external factors of organisation and the organisation stakeholders' interests and wishes. In the framework of the research, several SR organisations were observed. The majority of them are medium or large organisations. They are active in collaboration and communication with their stakeholders. SR organisations usually have a separate employee or a department that deals with HR affairs. Those organisations realise that their employees are their source of competitiveness. SR organisations usually develop the HRM strategy that is based on SR working principles. The summarised scheme of HR selection activity implementation highlights its specifics at SR organisations. SR organisation has a holistic view on each HR selection activity. SR organisations admit HR selection causes; they are able to ensure a necessary direction of the process implementation and plan or forecast types, range and characteristics of the HR selection outcomes.

Corporate social responsibility companies oriented to sustainability with a positive employer brand are the targets for many job seekers nowadays. Modern HR selection approaches within common selection procedures are meaningful and helpful. Nowadays it is easier to hire people, who are abroad or find the most suitable person among a big pool of applicants. The special software and Internet applications make HR selection faster and easier for a competence-based selection.

However, it is important to remember about ethical and legislative parts of human resource selection process. HR selection is not just an activity, which helps find employees according to corporate culture, objectives, and strategy; it is a link between the company and its stakeholders.

The results of the present research could be used as a ground for further studies on HR selection and SR strategy.

\section{REFERENCES}

Accenture Latvia, (2013). „Accenture Schools,” Accenture Latvia. [Online]. Facebook, Retrieved Aug. 18, 2013, from https://www.facebook.com/AccentureLatvia.

Armstrong, M. (2009). Armstrong's Handbook of Human Resource Management Practice. 11th ed. London/Philadelphia: Kogan Page Ltd.

Bartlett, Ch. A., \& Wozny, M. (2001). Microsoft: Competing on Talent (A), Harvard Business School Case 300-001, 1-28.

Bloisi, W. (2006). An Introduction to Human Resource Management. McGraw-Hill: Higher Education.

Boitmane, I. (2008). Personāla atlase un novērtēšana. Rīga: SIA «Lietišķs informācijas dienests».

Carroll, A. B. (1991). The pyramid of corporate social responsibility: Toward the moral management of organizational stakeholders, Business Horizons, 34(4), 39-48. http://dx.doi.org/10.1016/0007-6813(91)90005-G

Cascio, W. F. (1989). Managing Human Resources: Productivity, Quality of work life, profits, 2nd ed. New York: McGraw-Hill.

Cato, M. S. (2009). Green economics: An introduction to theory, policy and practice. London: Earthscan.

Clarke, E. (2006). People Management, Power brokers, 12(10), 40-42, 18 May.

Cooper, D., Robertson, I. T., \& Tinline, G. (2003). Recruitment and Selection: A Frame for Success. London: Thomson Learning.

Dessler, G. (2010). Human Resource Management, 12thed. New Jersey: Pearson Education, Inc.

Dombrovska, L. R. (2009). Cilvēkresursu kapitāla vadība. Rīga: Zvaigzne ABC.

Ešenvalde, I. (2008). Personāla vadības musdienu metodes. Rīga: Merkūrij LAT.

European Commission (2001). Promoting a European framework for corporate social responsibility. Green Paper: European Commission Directorate-General for Employment and Social Affairs. EC-Retrieved Apr. 1, 2012, from http://eur-lex.europa.eu/LexUriServ/site/en/com/2001/com2001_0366en01. pdf

Farnham, D. (2010). Human Resource Management in Context: Strategy, Insights and Solutions, 3rd ed. London: Chartered Institute of Personnel\& Development.

Foot, M., \& Hook, C. (2008). Introducing Human Resource Management, 5th ed. Harlow: Pearson Education.

Freeman, R. E. (1984). Strategic management: A stakeholder approach. Boston: Pitman.

French, W. L. (2007). Human Resources management, 6th ed. New York: Houghton Mifflin Company.

Graham, H. T., \& Bennett, R. (1998). Human Resources Management, 9th ed. Essex: Financial Times Management.

Gratone, L. (2004). Cilvēkresursu stratēǵtija. Rīga: SIA “J.L.V."

Griseri, P., \& Seppala, N. (2010). Business Ethics and Corporate Social Responsibility. Hampshire: Cengage Learning EMEA.

Ilgtspējas Indekss, (2014). Atzinību par ilgtspējīgu un atbildīgu uzñēmējdarbības praksi sañēmis 51 uzñēmums, Ilgtspējas Indekss. [Online]. Ilgtspējas Indekss, Retrieved Jan. 2, 2015, from http://www.ilgtspejasindekss.lv/ news.php?id=133.

Ilmete, Ż., \& Roišs, P. J. A. (1998). Personāla vadīšana Latvijā: pieredze un vīzijas. Rīga: LU.

Kehre, M. (2004). Personālmenedžments uzn̦ēmumā. Rīga: Biznesa augstskola Turība.

Lapina, I., Borkus, I. \& Starineca, O. (2012). Corporate Social Responsibility and Creating Shared Value: Case of Latvia, in World Academy of Science, Engineering and Technolog: Special International Journal Issues, pp. 1886-1892. 
Lapiṇa, I., Maurāne, G., \& Stariņeca, O. (2012). Stakeholders and Human Resources: Socially Responsible Strategy, in International Scientific Conference 53rd Riga Technical University Conference SCEE'2012 Scientific Conference on Economics and Entrepreneurship, pp. 1-6.

Lapina, I., Maurāne, G., \& Starineca, O. (2013). Holistic Human Resource Management Model towards Sustainable and Sophisticated Business, in the 17th World Multi-Conference on Systemics, Cybernetics and Informatics, Proceedings, pp. 31-36.

Legge, K. (1995). Human Resource Management: Rhetorics and Realities. London: Macmillan. http://dx.doi.org/10.1007/978-1-349-24156-9

Lundy, O., \& Cowling, A. (2003). Strategic Human Resource Management. London: Thomson Learning.

Mitchell, R. K., Age, B. R., \& Wood, D. J. (1997). Toward a Theory of Stakeholder Identification and salience: Defining the Principle of Who and What Really Counts, Academy of Management Review, 22(4), 853-886, Oct.

Porter, M. E. (1985). Competitive Advantage: Creating and sustaining superior performance. New York: The Free Press.

Porter, M. E., \& Kramer, M. R. (2011). Creating Shared Value How to reinvent capitalism - and unleash a wave of innovation and growth, Harvard Business Review, 1(1-2), 62-77.

Rahman, S. (2011). Evaluation of Definitions: Ten Dimensions of Corporate Social Responsibility, World Review of Business Research, 1(1), 166-176.

Raphael, M. A. (2009). Recruiting and Selection: From the HR Course to Practice, Northeast Business \& Economics Association Proceedings, pp. 180-182.

Savage, G. T., Nix, T. W., Whitehead, C. J., \& Blair, J. D. (1991). Strategies for assessing and managing organizational stakeholders, Academy of Management Executive, 5(2), 61-75. http://dx.doi.org/10.5465/ame.1991.4274682

Snell, S., \& Bohlander, G. (2011). Managing Human resources, 16th ed. South-Western: Cengage Learning.

Vīksna, A. (1999). Personāla vad̄̄ba. Rīga: Jumava.

Visser, W. (2011). The Age of Responsibility: CSR 2.0 and the New DNA of Business, Jornal of Business Systems, Governance and Ethics, 5(3), 7-22.

Vorončuka, I. (2009). Personāla vadība. Rīga: Latvijas univesritāte.

Werner, S., Schuler, R. S., \& Jackson, S. E. (2012). Human Resource Management, 11th ed. South-Western: Cengage Learning.

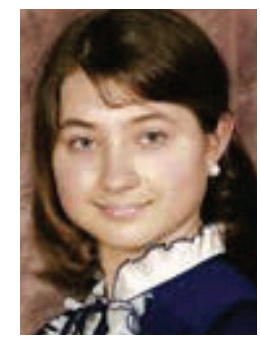

Olga Starineca obtained B. sc. oec. degree in Management in 2011 and M. sc. oec. degree in Management (MSM) in 2013 from Riga Technical University, Latvia, and at present continues her studies at the University of Latvia to gain a Doctor of Social Sciences degree (Dr. sc. admin.) in Management.

From March to August 2012 she took an internship with the European Commission, Department of HR and Security, conducting research on ethical issues in the public sector. She has worked as a Senior Teacher Assistant at Stockholm School of Economics in Riga on HRM course for Bachelor students since August 2013. At present, she works as a Lecturer on HRM and Personnel Management courses for Bachelor students at Riga Stardins University and the University of Latvia. Previous publications:

Stariņeca, O., and Voronchuk, I. (2014). Employer Branding Training Development for Public Organisations. Regional Formation and Development Studies, 3 (14), 207-219. doi: 10.15181/rfds.v14i3.877.

Voronchuk, I., and Starineca, O. (2014). Knowledge Management and Possibilities of Professional Development in Public Sector. European Integration Studies, 8, 168-179. doi: 10.5755/j01.eis.0.8.6844.

Her research interests lay in human resource management, public administration, and social responsibility issues.

E-mail: Olga.Starineca@rtu.lv 